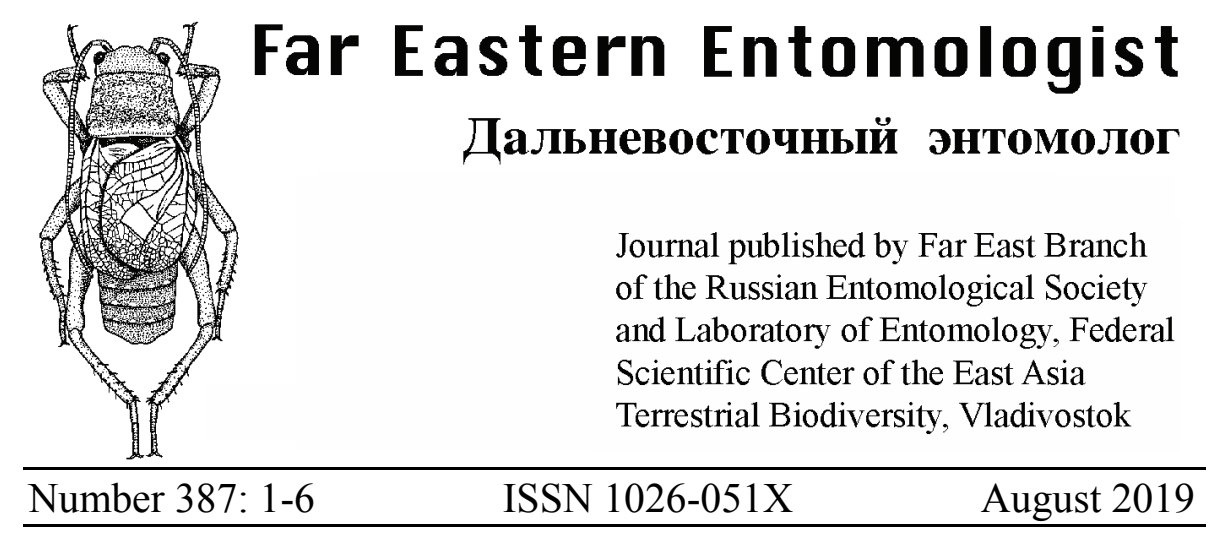

https://doi.org/10.25221/fee.387.1

http://zoobank.org/References/B8DFF99F-B7F1-42B5-B9B5-D685FB6E8769

\title{
A NEW SPECIES OF THE GENUS TAMDAOTETTIX (ORTHOPTERA: RHAPHIDOPHORIDAE) FROM YUNNAN WITH A KEY TO CHINESE SPECIES
}

\author{
Yanyan Qin ${ }^{1)}$, Hanqiang Wang ${ }^{2)}, \mathrm{Kai}_{\mathrm{Li}^{1}}{ }^{1, *)}$
}

1) School of Life Sciences, East China Normal University, Shanghai 200241, China.*Corresponding author,E-mail: kaili@admin.ecnu.edu.cn

2) Shanghai Entomology Museum, Chinese Academy of Sciences, Shanghai 200032, China.

Summary. A new species Tamdaotettix (Laotettix) truncatus Qin, Wang et Li, sp. n. is described from China (Yunnan). New species is most similar to T. (L.) curvatus Gorochov et Storozhenko, 2015 but differs from the latter in the shape of male 6th and 7 th abdominal tergites and the shape of female subgenital plate. A key to the Chinese species of the genus is provided.

Key words: Orthoptera, Rhaphidophoridae, Tamdaotettix, taxonomy, key, new species, South Asia.

Я. Цинь, Х. Ванг, К. Ли. Новый вид рода Tamdaotettix (Orthoptera: Rhaphidophoridae) из провинции Юньнань с определительной таблицей китайских видов // Дальневосточный энтомолог. 2019. N 387. С. 1-6.

Резюме. Из провинции Юньнань (Китай) описан новый вид Tamdaotettix (Laotettix) truncatus Qin, Wang et Li, sp. n. Новый вид наиболее близок к T. (L.) curvatus Gorochov et Storozhenko, 2015, но отличается от него формой 6-го и 7го тергитов брюшка самца и генитальной пластинки самки. Также приведена определительная таблица известных из Китая видов рода. 


\section{INTRODUCTION}

The genus Tamdaotettix Gorochov, 1998 consists of 17 species distributed in Laos, Vietnam and South China (Gorochov \& Storozhenko, 1992; Gorochov, 1998; Gorochov \& Storozhenko, 2015; Qin et al., 2016; Zhu et al., 2018; Cigliano et al., 2019; Gorochov \& Storozhenko, 2019). It was divided into two subgenera: Tamdaotettix s. str. and Laotettix Gorochov et Storozhenko, 2015. Up to now, there are 11 species in the nominotypical subgenus: $T$. (T.) aculeatus Gorochov et Storozhenko, 2015 (Vietnam), T. (T.) ailaoshanicus Gorochov et Storozhenko, 2019 (China: Yunnan), T. (T.) dilutus (Gorochov, 1998) (Vietnam; China: Yunnan), T. (T.) flexus Gorochov et Storozhenko, 2015 (Vietnam), T. (T.) laocai Gorochov et Storozhenko, 2015 (Vietnam), T. (T.) longituberus Zhu, Bian et Shi, 2018 (China: Guangxi), T. (T.) minipullus Gorochov et Storozhenko, 2019 (Vietnam), T. (T.) pullus (Gorochov, 1998) (Vietnam), T. (T.) semipullus (Gorochov, 1998) (Vietnam), T. (T.) tridenticulatus Qin, Liu et Li, 2016 (China: Guangxi, Guizhou), and T. (T.) vinhphuensis (Gorochov, 1992) (Vietnam). The subgenus Laotettix consists of five species: $T$. (L.) curvatus Gorochov et Storozhenko, 2015 (Laos, China: Yunnan), T. (L.) inflatus Gorochov et Storozhenko, 2015 (Laos), T. (L.) minutus Gorochov et Storozhenko, 2015 (Laos), T. (L.) sympatricus Gorochov et Storozhenko, 2015 (Laos), and T. (L.) tarasovi Gorochov et Storozhenko, 2015 (Laos). The subgeneric position of Tamdaotettix robustus Gorochov et Storozhenko, 2015 from Vietnam is uncertain.

In this paper, a new species of the subgenus Laotettix is described and a key to species of the genus Tamdaotettix distributed in China is provided.

\section{MATERIAL AND METHODS}

The type specimens are deposited in Shanghai Entomological Museum, Chinese Academy of Sciences (SEM). Morphological characteristics were examined using a Leica MZ 125 dissecting microscope and illustrated with aid of a drawing tube attached to the microscope. Line arts were produced by Adobe Illustrator CS5 graphic software.

\section{TAXONOMY}

Family Rhaphidophoridae Walker, 1869

Subfamily Aemodogryllinae Jacobson, 1905

Tribe Diestramimini Gorochov, 1998

Genus Tamdaotettix Gorochov, 1998

Tamdaotettix Gorochov, 1998: 81; Storozhenko \& Dawwrueng, 2014: 289; Gorochov \& Storozhenko, 2015: 52; Qin et al., 2016: 339; Zhu et al., 2018: 294; Gorochov \& Storozhenko, 2019: 151 .

Type species: Tamdaotettix dilutus Gorochov, 1998, by original designation. 
DIAGNOSIS. Body is smaller than in majority of the other genera of Diestramimini. Pronotum with dorsal edge arcuate and convex. Male posteromedian process of 7 th abdominal tergite rather short; posteromedian process of 6 th abdominal often angular or spine-like. Male paraproct simple. Male genitalia consists of six rather simple and completely membranous lobes (three dorsal and three ventral lobes; the ventrolateral lobes not very long and undivided). Female paraproct simple; upper valve of ovipositor with distinct dorsal notch near apex or without it. Tamdaotettix is most similar to the genus Mimadiestra Storozhenko et Dawwrueng, 2014 but differs from the latter in characters given in a key (Gorochov \& Storozhenko, 2015).

COMPOSITION. There are 17 species known from Laos, Vietnam and South China. Up to now five species has been recorded from Yunnan, Guizhou and Guangxi provinces of China. One new species is described in present paper. A key to six Chinese species is given below.

\section{Key to Chinese species of Tamdaotettix}

1. Male: posteromedian process of 6th abdominal tergite with apex angular or spinelike. Female: subgenital plate slightly transverse and apex not truncated (subgenus Tamdaotettix s. str.)

- Male: posteromedian process of 6th abdominal tergite without angular or spine-like apex; subgenital plate of female strongly transverse and apex almost truncated or concave (subgenus Laotettix)

2. Male: posteromedian process of 6 th abdominal tergite with a long spine-like projection, its apex obviously reaching apex of process of 7 th abdominal tergite ....... T. (T.) longituberus Zhu, Bian et Shi, 2018

- Male: posteromedian process of 6th abdominal tergite with a short spine-like projection, its apex not reaching apex of process of 7 th abdominal tergite 3

3. Male: posteromedian process of 6 th abdominal tergite with a small angular projection, its apex obviously shorter than the process of 7 th abdominal tergite; process of 7 th abdominal tergite with 3 spines in hind margin

T. (T.) tridenticulatus Qin, Liu et Li, 2016

- Male: posteromedian process of 6th abdominal tergite triangular, basal area slightly broad, gradually narrowing to apex, its apex almost equal to process of 7 th abdominal tergite; process of 7 th abdominal tergite short and broad, apex acute ........ 4

4. Male: posteromedian process of 6 th abdominal tergite without apical denticles .... T. (T.) dilutus Gorochov, 1998

- Male: posteromedian process of 6th abdominal tergite with a pair of apical denticles .................................. T. (T.) ailaoshanicus Gorochov et Storozhenko, 2019

5. Male: posteromedian process of 6th abdominal tergite with apex blunt, the apex not reaching apex of process of 7 th abdominal tergite. Female: subgenital plate roundly truncate at apex ............ T. (L.) curvatus Gorochov et Storozhenko, 2015

- Male: posteromedian process of 6 th abdominal tergite with apex truncated, the apex reaching apex of process of 7 th abdominal tergite. Female: subgenital plate distinctly concave at apex $T$. (L.) truncatus Qin, Wang et Li, sp. n. 
Tamdaotettix (Laotettix) truncatus Qin, Wang et Li, sp. n.

http://zoobank.org/NomenclaturalActs/9D16AB12-3ED1-439E-A3C2-2D67BE2063BA

Figs 1-5

TYPE MATERIAL. Holotype - $\widehat{\jmath}$, China: Yunnan province, Nabanhe N. R., Bangganghani, 2200-2300 m, 29.IV 2009, leg. Jia-Yao Hu \& Zi-Wei Yin (SEM). Paratypes: $1 \hat{\jmath}, 2+$, the same data as the holotype (SEM).
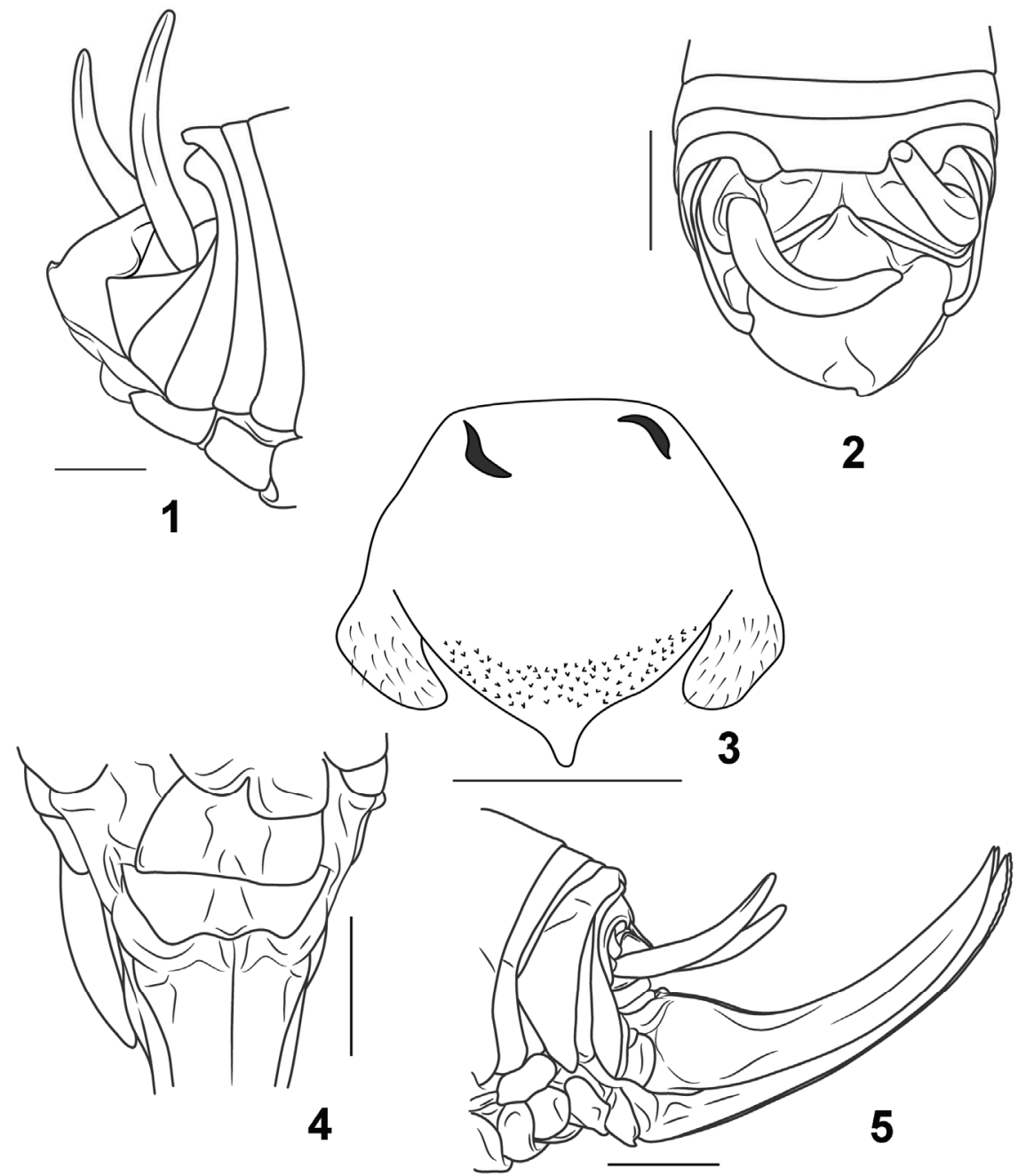

Figs. 1-5. Tamdaotettix (Laotettix) truncatus sp. n. 1 - male abdominal apex, lateral view; 2 - male abdominal apex, dorsal view; 3 - male genitalia, dorsal view; 4 - female abdominal apex, ventral view; 5 - female abdominal apex, lateral view. Scale bar $=1 \mathrm{~mm}$. 
DESCRIPTION. MALE. Body small, shinning. Head with fastigium of vertex divided into two conical tubercles, completely fused. Legs slender; fore femur about 1.3 times as long as the pronotum, beneath unarmed, external genicular lobe with a long movable spine; fore tibiae beneath with 2 external and 2 internal movable spines, between the paired apical spurs with a short spur. Mid femur with a long movable spine on the external and internal genicular lobe; mid tibiae beneath with 2 external and 1 internal movable spines, between the paired apical spurs with a short spur. Hind femur beneath with 5-6 external small spines and without external spines; hind tibiae above with 50-54 outer spines and 45-49 inter spines, inner supra apical spur of hind tibiae slightly longer than the hind metatarsus. Hind metatarsus with 2-3 dorsal spines, including the apical spine. Posteromedian process of 6 th abdominal tergite with a truncated apex, reaching the apex of 7 th abdominal tergite, its apex obviously wider than apex of 6th abdominal tergite (Figs 1, 2). Male genitalia: dorsolateral lobes short, dorsomedian lobe broad with lingua-like apical part (Fig. 3).

FEMALE. Subgenital plate transverse, at middle part of hind margin with a small projection (Fig. 4). Ovipositor shorter than the half of hind femur; upper valve of ovipositor without dorsal notch near apex (Fig. 5).

COLORATION. Body dark brown, shinning. Tergites with a greyish white band, the length of band is variable in different specimens. Frons light, with four dark longitudinal bands from vertex to clypeus. Legs dark brown, without obvious stripes.

MEASUREMENTS (length in mm). Body: ô 8.0-10.0, क 8.5-10.0; pronotum:

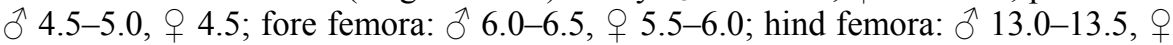
missing femora; hind tibiae: $\widehat{\delta} 13.5-14.5$, + missing tibiae; ovipositor + 6.0-6.5.

DIAGNOSIS. The new species is similar to Tamdaotettix (Laotettix) curvatus Gorochov et Storozhenko, 2015, but differs from the latter in the male posteromedian process of 6 th abdominal tergite with a truncated apex, which reaches apex of process of 7 th abdominal tergite, but the process of 7 th tergite obviously wider than the former (Figs 1,2) (in T. curvatus, the process of 6th abdominal tergite with blunt apex, process of 7 th abdominal tergite with concave apex, apex of 6th tergite process not reaching apex of 7 th tergite process).

DISTRIBUTION. China (Yunnan).

ETHYMOLOGY. This species is named after a truncated apex of male posteromedian process of 6 th abdominal tergite.

\section{ACKNOWLEDGEMENTS}

The authors thank to Ziwei Yin (Shang Hai Normal University, China) who presented the specimens for us to study. This research was supported by the Sciencetechnology basic condition platform from The Ministry of Science and Technology of the People's Republic of China (2005DKA21402) and Science Big Data Project (XXH13505-03-102-4).

\section{REFERENCES}

Cigliano, M.M., Braun, H., Eades, D.C., \& Otte, D. 2019. Orthoptera Species File. Online. Version 5.0/5.0. Available from: http://Orthoptera.SpeciesFile.org. (Accessed: 2 April 2019). 
Gorochov, A.V. 1998. Material on the fauna and systematics of the Stenopelmatoidea (Orthoptera) of Indochina and some other territories. Entomologicheskoe Obozrenie, 77(1): 73-105. [In Russian; English translation in Entomological Review, 78(1)]

Gorochov, A.V. \& Storozhenko, S.Yu. 1992. On the fauna of the subfamily Aemodogryllinae (Orthoptera, Rhaphidophoridae) in Vietnam. Proceedings of the Zoological Institute of the Russian Academy of Sciences, 245: 17-34. [In Russian]

Gorochov, A.V. \& Storozhenko, S.Yu. 2015. New and little-known taxa of the tribe Diestramimini (Orthoptera: Rhaphidophoridae: Aemodogryllinae) from Southeast Asia. Part1. Zoosystematica Rossica, 24(1): 48-84.

Gorochov, A.V. \& Storozhenko, S.Yu. 2019. New and little-known taxa of the tribe Diestramimini (Orthoptera: Rhaphidophoridae: Aemodogryllinae) from Southeast Asia. Part 2. Zoosystematica Rossica, 28(1): 132-154. DOI: 10.31610/zsr/2019.28.1.132

Qin, Y. Y., Liu, X.W. \& Li, K. 2016. Review of the cave cricket genus Tamdaotettix Gorochov with a new species and some new descriptions (Orthoptera: Rhaphidophoridae, Aemodogryllinae). Zootaxa, 4154(3): 339-345. DOI: 10.11646/zootaxa.4154.3.9

Storozhenko, S.Yu. \& Dawwrueng, P. 2014. New genus of the tribe Diestramimini (Orthoptera: Rhaphidophoridae) from Thailand. Zootaxa, 3765(3): 288-294. DOI: 10.11646/zootaxa.3765.3.5

Zhu, Q.D., Bian, X. \& Shi, F.M. 2018. Remarks on the genus Tamdaotettix Gorochov, 1998 (Orthoptera: Rhaphidophoridae: Aemodogryllinae) from China. Zootaxa, 4378(2): 294300. DOI: $10.11646 /$ zootaxa.4378.2.11 